\title{
RELATIONSHIP BETWEEN MYCELIAL INOCULUM OF Sclerotinia sclerotiorum AND PERFORMANCE OF SUNFLOWER SEEDS UNDER CONTROLLED CONDITIONS
}

\author{
RELAÇÃO ENTRE INÓCULO MICELIAL DE Sclerotinia sclerotiorum E O \\ DESEMPENHO DE SEMENTES DE GIRASSOL EM CONDIÇÕES CONTROLADAS
}

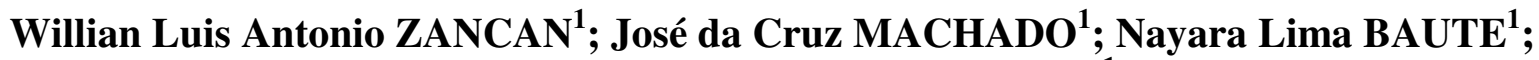 \\ Bruno Figueiredo Moretti de SOUSA ${ }^{1}$ \\ 1. Federal University of Lavras, Seed Pathology Laboratory, Lavras, Minas Gerais, Brazil. zancanwillian@gmail.com
}

\begin{abstract}
The cultivated area of sunflower in Brazil is expanding considerably over the last years as the result of the great interest in the biodiesel production derived from that crop. One consequence of that expansion is the occurrence of several diseases some of devastating nature in part of the growing areas with sunflower. This study evaluated the effects of the association of sunflower seeds infected by Sclerotinia sclerotiorum and the pathogen transmission rates from these infected seeds, considering some factors which may interfere in that interaction. Four inoculum potentials, two isolates of the cited fungus, two sunflower cultivars, 'Helio 250' and 'Helio 253' and two environmental temperatures, $20^{\circ} \mathrm{C}$ and $25^{\circ} \mathrm{C}$, were used for the purpose in this work. Seed germination and health, emergence speed index, and plant populations were variables analyzed. From the results, increased levels of inoculum potentials led to gradual reduction of the mean values of germination, emergence rate index and plant populations, regardless the genotype, fungal isolates and temperatures. Transmission rates were higher at the highest levels of inoculum potential, the maximum reaching $80 \%$. These results show the significance of S. sclerotiorum inoculum associated with sunflower seeds both in the establishment of plants in fields and also in spreading the pathogen inoculum between crop fields.
\end{abstract}

KEYWORDS: Helianthus annuus. Physiologic conditioning. Transmission. White mold.

\section{INTRODUCTION}

Helianthus annuus L. is susceptible to several diseases and among them white mold caused by Sclerotinia sclerotiorum (Lib.) de Bary is one of the most devasting around the world. This disease is distributed worldwide and its causal agent may cause infection to several other crops. Over 408 species and 278 genera of plants have been reported host that pathogen (BOLAND; HALL, 1994), which may survive in soil for several years as resting structures, sclerotia. Those structures are able to infect plants through myceliogenic and carpogenic processes (BOLTON et al., 2006).

Infected seeds play an important role in the cycle of white mold of sunflower as primary inoculum source in the field and for spreading the disease to long distances. Due to its parasitic and survival nature, $S$. sclerotiorum is considered a pest of high risk in Brazil, being considered as a non quarantine regulated pest in certification seed programs of soybean, dry bean, cotton and sunflower. In those cases the presence of $S$. sclerotiorum in association with seeds, either as sclerotia or internal mycelium is not acceptable (BRASIL, 2009a). From previous studies conducted by Tu (1988) S. sclerotiorum is known to be able to survive in infected bean seeds as dormant mycelia in testa and cotyledons for 3 years or longer and when infected seeds were sown, $88-100 \%$ failed to germinate. Seedlings from infected seeds subsequently died from white mold at an early stage and the seeds that failed to germinate were rotted by the pathogen and three to six sclerotia were formed in place from each seed.

Nevertheless, only a few reports are found in literature giving information on the importance of S. sclerotiorum mycelia in seeds of different hosts, including sunflower. Therefore, the interaction between that pathogen and seeds of sunflower remains little understood and it should be demonstrated and quantified on scientific basis.

Quantification of losses caused by white mold in sunflower crop is little known from literature. However it is well known from sunflower growers that such disease is able to reduce yield to a large extent, being a serious threat in a large area in Brazil where this crop is explored.

This study quantified the effects of $S$. sclerotiorum from infected seeds on sunflower early stage development and to determine the potential transmission rates of $S$. sclerotiorum from mycelial infected seeds under controlled growing conditions. 


\section{MATERIAL AND METHODS}

\section{Obtaining and multiplication of fungal isolates}

Two isolates of $S$. sclerotiorum used in this study were obtained from sunflower seeds, collected in Lavras, State of Minas Gerais MG (CMLAPS 250) and Montividiu - State of Goiás (CMLAPS 423), both belonging to the mycological collection of the Seed Pathology Laboratory of the Federal University of Lavras. The isolates were grown initially on PDA media plates and incubated at $20 \pm$ $2^{\circ} \mathrm{C}$, with a photoperiod of 12 hours for five days.

\section{Seed inoculation procedures}

Seeds of two sunflower cultivars, 'Helio 250' (C1) and 'Helio 253' (C2), were disinfested with sodium hypochlorite $1 \%$ for 30 seconds, rinsed in distilled water and then left to dry for 48 hours in a laminar flow hood, on germitest paper. The seed inoculation was done by the osmotic technique developed by Costa et al. (2003) and Machado et al. (2012). By that technique, PDA substrate modified osmotically by the solute mannitol, at water potential of $-1.4 \mathrm{MPa}$ adjusted by software MPPS (MICHEL; RADCLIFFE, 1995) was poured to Petri dishes of $15 \mathrm{~cm}$ diameter. Mycelial plugs of $S$. sclerotiorum isolates were placed on the media and then kept in an incubation chamber at $20^{\circ} \mathrm{C}$ and photoperiod of 12 hours for five days. On the top of the fungal colonies disinfested seeds were distributed in a single layer, making sure all seeds were placed in contact with the fungal mycelium. The dishes were then transferred to incubation chamber at $20^{\circ} \mathrm{C}$ for the periods: $24 \mathrm{~h}(\mathrm{P} 1), 48 \mathrm{~h}$ (P2), 72h (P3) and 96h (P4) hours, each period standing for one inoculum potential of the pathogen. A control was prepared for each incubation period using the same seed substrate with mannitol in the absence of S. sclerotiorum.

\section{Assessing the quality of sunflower seeds infected by Sclerotinia sclerotiorum in different levels of inoculum potential}

The health condition and physiological performance of the infected and non infected seeds were evaluated according to protocols described in Brazil (2009b). The seed health test consisted in incubation of seeds on a semi seletive-bromophenol agar substrate (NEON), as widely described in literature (NASSER et al., 1999; PERES et al., 2002; NAPOLEÃO et al., 2006), using a total of 200 seeds of control and inoculated seeds for each inoculum potential. The plates were distributed in incubation chamber at $20^{\circ} \mathrm{C}$. At the third and fifth days of incubation, the seeds were examined for the formation of yellow-red halos around seeds, which is an indication of the presence of S. sclerotiorum in them. The plates were also analyzed in stereo microscope for mycelium growth and presence of sclerotia of that fungus (BRAZIL, 2009b).

Standard germination test was run by the roll paper method (BRAZIL, 2009b) in which 200 seeds per treatment were used with incubation of seeds in germination cabinet with temperature adjusted to $25 \pm 2{ }^{\circ} \mathrm{C}$. Evaluation was made on the fifth and ninth day, according to Brazil, 2009a.

To evaluate the emergence speed index, initial and final stands, seeds were sown in $300 \mathrm{~mL}$ plastic cups containing a 2:1 mixture of sand and substrate (Tropstrato HA Hortaliças). For each cultivar, 100 inoculated seeds and 100 of non inoculated seeds were sown, each seed being planted in single plastic cups, of $300 \mathrm{~mL}$ which were placed together in polyethylene boxes for a total of four boxes per cultivar and inoculums potential. The experiment was conducted in a growth rooms at 20 and $25^{\circ} \mathrm{C}$. The seedling/plant emergence rate was determined by daily counts of seedlings until the stabilization of plant population. The ratio of emergence rate was calculated according to formula described by Maguire (1962).

\section{Determination of potential transmission rate of Sclerotinia sclerotiorum from sunflower seeds to plants}

The total transmission rate was estimated by the sum of the number of seeds/seedlings killed in pre-emergence as the result of the pathogen action plus the number of emerged plants with symptomatic infection and asymptomatic disease (Baker and Smith, 1966; Bergstrom and Shah, 2000). Plants were considered symptomatic when presenting wilt followed by necrosis or dampingoff. In V3 growth stage (15 days after sowing DAS), one of the cotyledons of each plant was collected and, at 25 DAS, each plant was sectioned in three parts (cotyledon/stem insertion, apex and root crown). The evaluation was carried out by the destructive method, collecting the four fragments, $1.5 \mathrm{~cm}$ size, of each plant. All sections were disinfested in $70 \%$ alcohol sodium hypochlorite and $1 \%$ sterile distilled water for $1 \mathrm{~min}$. After drying on paper towels, fragments of the same plant were distributed on semi-selective agar bromophenol (Neon) medium in Petri dishes and kept in an incubation at $20^{\circ} \mathrm{C}$ for seven days. After this period, the occurrence of mycelial growth from each plant was observed by the color change of the substrate and, when necessary, fungal structures were confirmed with the aid of light microscopy at $80 \mathrm{X}$ 
magnification. The transmission of the pathogen to the emerged plant and dead non emerged seedlings was considered positive when at least one fragment of the symptomatic or asymptomatic plant presented mycelial growth of $S$. sclerotiorum.

\section{Data analysis}

For germination and incidence were used 50 seeds for each cultivar, isolate and inoculum potential, in a total of 200 seeds per treatment. For emergence speed index, initial and final stands 25 seeds for each cultivar, isolate, mannitol and inoculum potential in a total of 100 seeds per treatment were used. The experimental design was complete randomized with four replications. Statistical analysis of variance (ANOVA) was performed by R statistical software v 2.15.1. Data were analyzed using Tukey test and P-value less than 0.05 was considered significant. Analysis was conducted in double factorial among cultivars and isolates (I 250, I 423 and mannitol) $x$ inoculum potential (P1, P2, P3 and $\mathrm{P} 4)$ in each temperature (20 and $25^{\circ} \mathrm{C}$ ). The graphics were prepared using the Sigma Plot 12.1 program (Systat Software Inc.).

\section{RESULTS}

\section{Relationship between inoculum potential and quality of sunflower seeds infected by $S$. sclerotiorum}

The initial germination percentages of sunflower seeds of the cultivars used in this study, 'Helio 250' and 'Helio 253' were 98\% and 93\%, respectively. From the seed health pre-test presence natural incidence of $S$. sclerotiorum was not found in the seed lots used.

Infected seeds by the two isolates of $S$. sclerotiorum presented in this work reductions in the variable germination according to the inoculum potentials used (Figure 1A). For one cultivar, 'Helio 250', the reduction was of $25 \%$ and $76.5 \%$ in relation to both isolates, CMLAPS 423 and CMLAPS 250, respectively. The reduction of that variable was even higher $(73 \%)$ for the cultivar 'Helio 253', for both isolates compared to the control.

Regarding the effect of the water restrictor used to inhibit seed germination during the inoculation of seeds in agar substrate in the absence of the pathogen, there was also a decline in the percentage of seed germination, proportional to the increase of the periods of time of contact between seeds and water restrictor in agar substrate. But the declining slope was not significant in comparison with the reduction observed when $S$. sclerotiorum was present in the agar substrate.

The incidence of $S$. sclerotiorum in sunflower seeds, as provided by the health testing, was correlated with inoculum potential of the fungus used for both cultivars and fungal isolates (Figure 1B). In relation to cultivars, it was observed a similar reaction to $S$. sclerotiorum isolates with a gradual increase in the incidence of infection, reaching $100 \%$ at the highest level of inoculum potential $(\mathrm{P} 4)$.
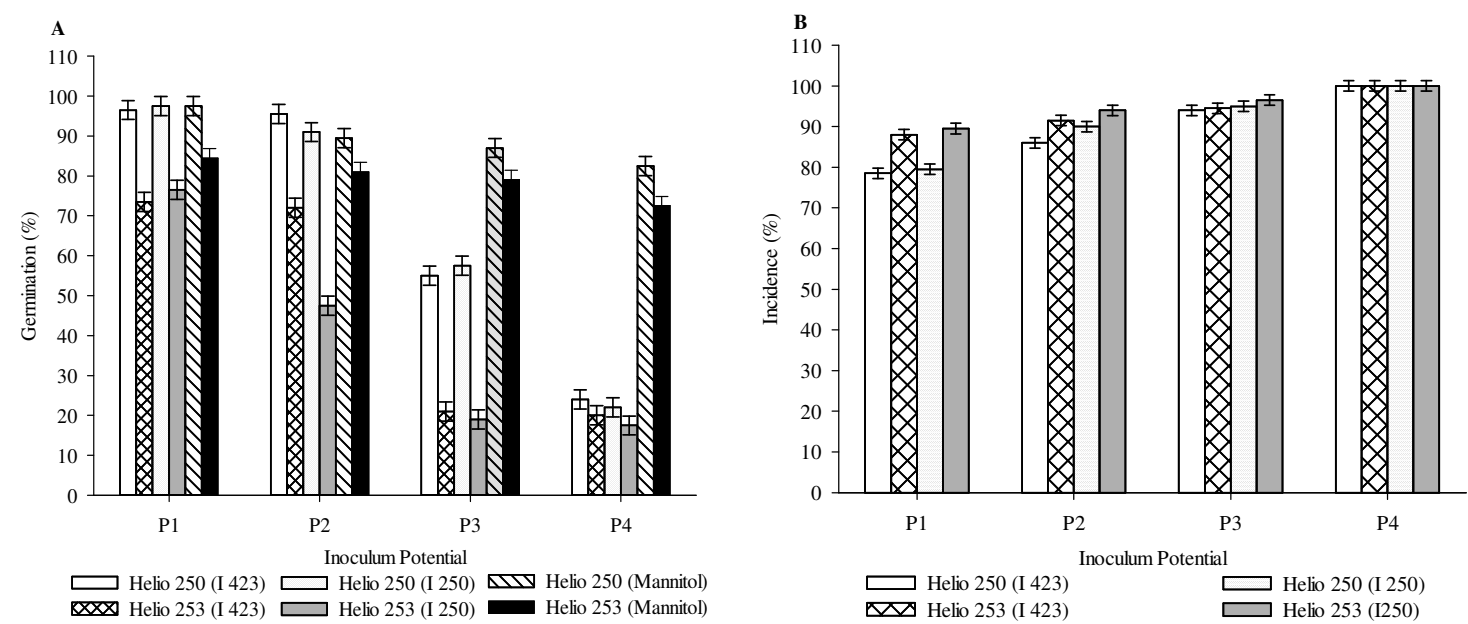

Figure 1. A) Percentage seed germination in sunflower infected by S. sclerotiorum in different inoculum potentials (P1, P2, P3, P4) of the fungus and B) incidence of $S$. sclerotiorum in sunflower seeds infected at different inoculum potentials. Bars represent Tukey 0.05 mean separation test; overlapping bars indicate lack of significant difference.

For the variables: emergence rate index, initial and final stands, variations were observed in the factors analyzed at different levels of seed infection (Figures 2, 3 and 4). The highest values of 
vigor (emergence rate index) were observed on the potential $\mathrm{P} 1$, this value decreasing with increasing inoculum potential, with similar trends regarding cultivars, isolates and temperature (Figure $2-\mathrm{A}$ and B). For sunflower seeds submitted to different periods of contact with the water restrictor in the absence of the pathogen, reductions were observed in the seed performance, but in smaller proportions compared to the treatments evaluated in the presence of the fungus.
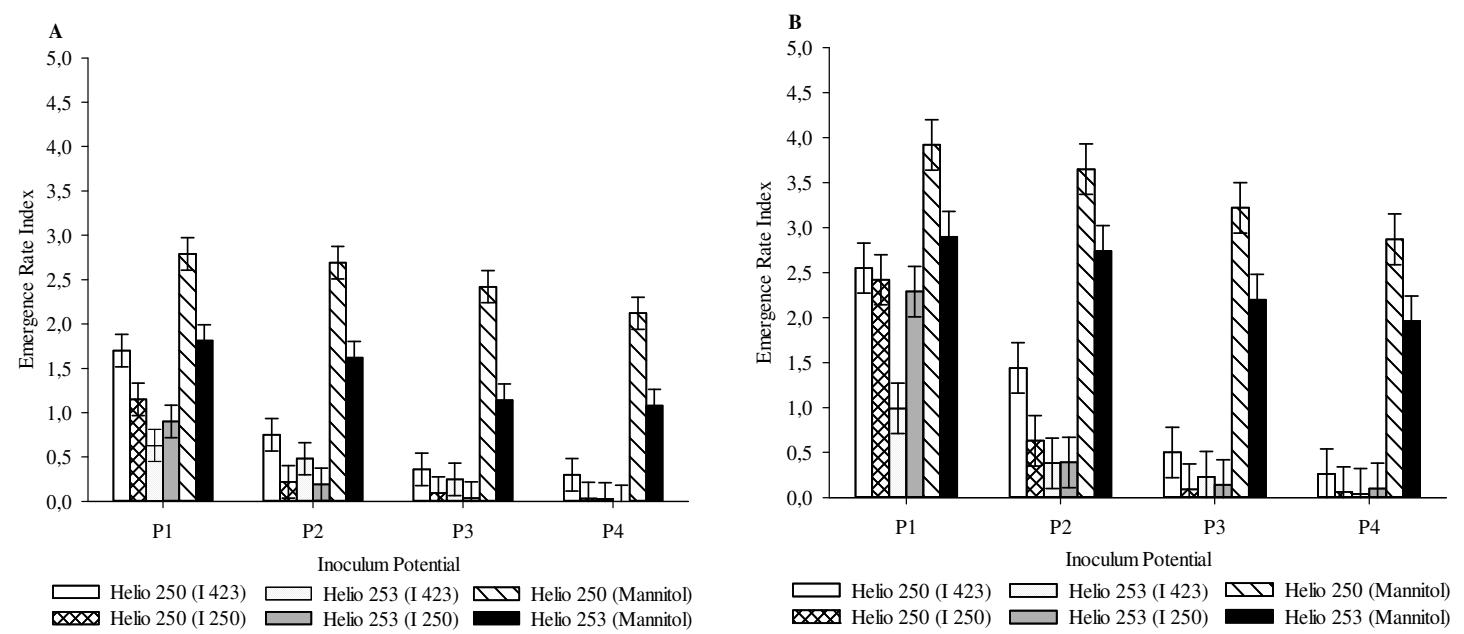

Figure 2. Emergence rate index of sunflower seeds, cultivars: 'Helio 250' and 'Helio 253' inoculated with two isolates of $S$. sclerotiorum (CMLAPS 250 and CMLAPS 423) in contact with the water restrictor (manitol) under temperatures of $20^{\circ} \mathrm{C}(\mathrm{A})$ and $25^{\circ} \mathrm{C}(\mathrm{B})$ in a growth room with different levels of inoculum potential. Bars represent Tukey 0.05 mean separation test; overlapping bars indicate lack of significant difference between treatments.

For the initial stand, at both temperatures of 20 and $25^{\circ} \mathrm{C}$ a drastic reduction was observed in the percentage of the plant population for both cultivars and isolates of $S$. sclerotiorum. The average values of initial reductions in the stands were approximately $95 \%$ on the higher inoculum potential compared to the lowest level. The cultivar 'Helio 250' infected with the isolate CMLAPS 423, for two temperatures 20 and $25^{\circ} \mathrm{C}$ (Figure 3 - A and B) showed a decline less severe in initial stand and emergence rate index in potential inoculum tested when compared with the other results, with the exception of potential $\mathrm{P} 4$, in which there was no difference among cultivars. These results show that the presence of S. sclerotiorum in association with sunflower seeds may cause seedling collapse in pre and post-emergence, reducing the plant population in crop fields.
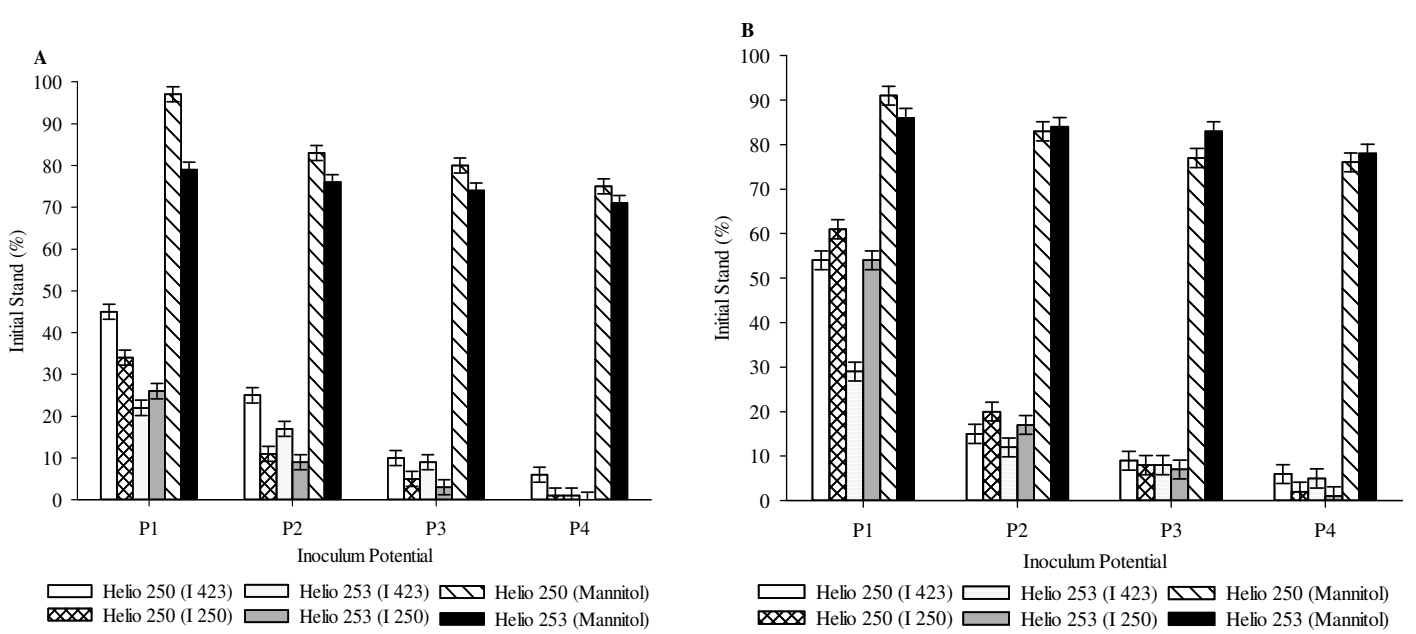

Figure 3. Initial Stand (\%) of sunflower seeds, cultivars: 'Helio 250' and 'Helio 253' inoculated with two isolates of S. sclerotiorum (CMLAPS 250 and CMLAPS 423) in contact with the water restrictor (manitol) under temperatures of $20^{\circ} \mathrm{C}$ (A) and $25^{\circ} \mathrm{C}$ (B) in a growth room with different levels of inoculum potential. Bars represent Tukey 0.05 mean separation test; overlapping bars indicate lack of significant difference. 
In relation to final stand, evaluated at 25 days after sowing, there was little variation among cultivars for each isolate at botht temperatures used (Figure 4-A and B). Under those temperatures the plant establishment was reduced largely, reaching up to $95 \%$ in the higher inoculum potential for both cultivars and isolates of $S$. sclerotiorum.

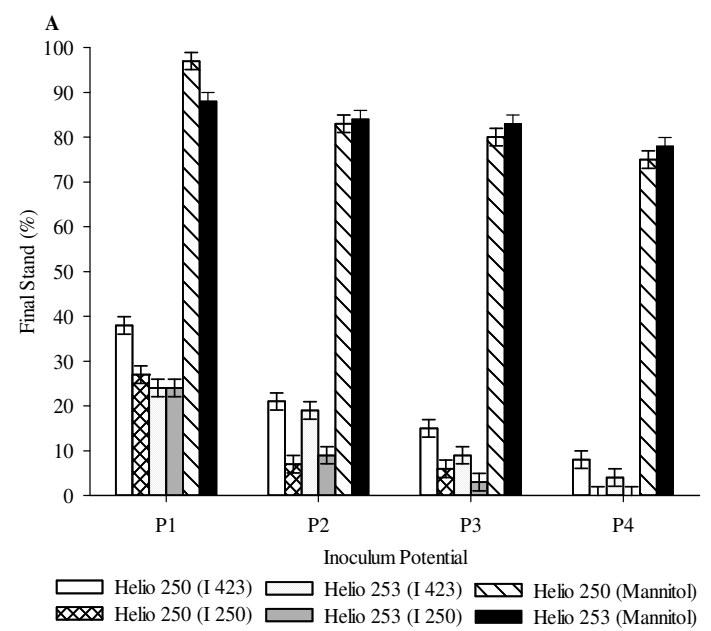

The reduction of the final stand was also observed in the treatment without the presence of $S$. sclerotiorum, but with the addition of mannitol to the agar medium. In this case there was an average reduction of $20 \%$ in the sunflower population under both temperatures $\left(20\right.$ and $\left.25^{\circ} \mathrm{C}\right)$.

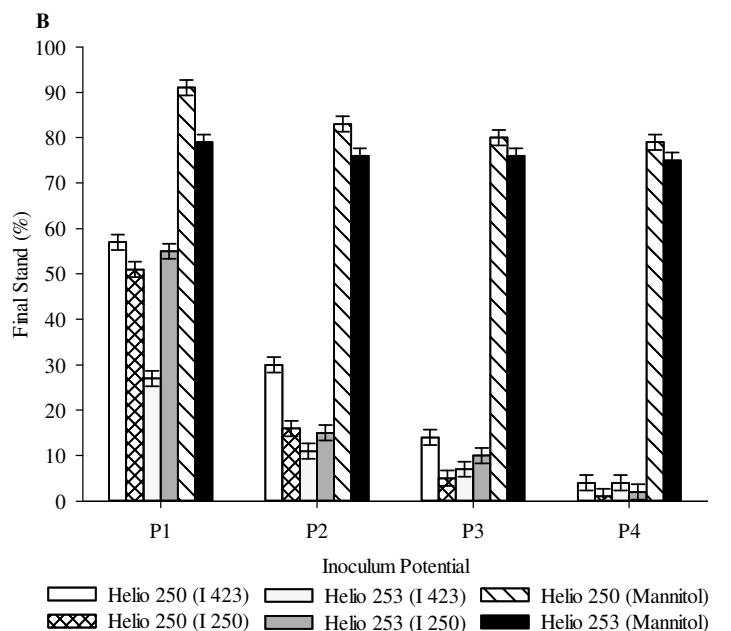

Figure 4. Final stand (\%) of sunflower seeds, cultivars: 'Helio 250' and 'Helio 253' inoculated with two isolates of S. sclerotiorum (CMLAPS 250 and CMLAPS 423) in contact with the water restrictor (manitol) under temperatures of $20^{\circ} \mathrm{C}$ (A) and $25^{\circ} \mathrm{C}$ (B) in a growth room with different levels of inoculum potential. Bars represent Tukey 0.05 mean separation test; overlapping bars indicate lack of significant difference.

From Figure 4 it is clear that the reduction in final stand was higher with an increase in inoculum potential of S. sclerotiorum in sunflower seeds, which can be better visualized in Figure 5, showing the effect of the fungus on cultivars and at distinct temperatures used in this work.

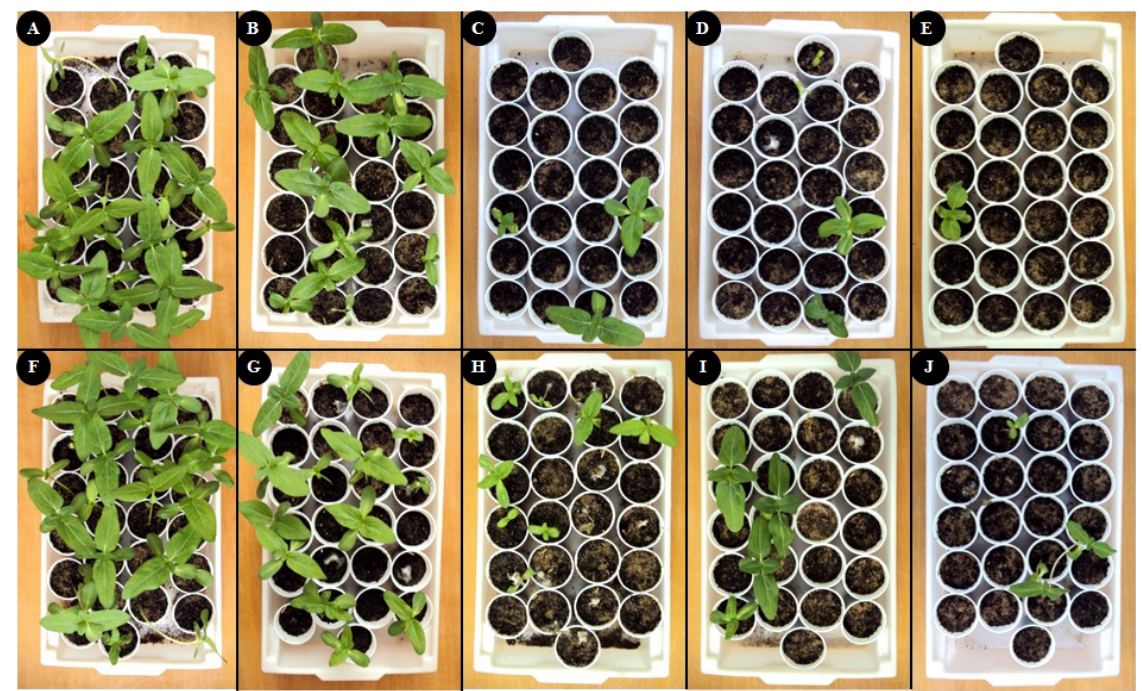

Figure 5. Final stands of the cultivar 'Helio $250^{\prime}$ in relation to inoculum potentials of two isolates at $20^{\circ} \mathrm{C}$. Top trays: referring to isolate CMLAPS 250 and inoculum potentials: P1 (B), P2 (C), P3 (D), P4 (E). Botton trays: referring to isolate CMLAPS 423 and inoculum potentials: P1 (G), P2 (H), P3 (I) and P4 (J). Trays A and F referring to the control. 


\section{Potential transmissibility of $S$. sclerotiorum by sunflower infected seeds under controlled conditions}

The transmission process based on assessment of white mold infections in symptomatic sunflower plants was demonstrated in this study, being the transmission rates directly proportional to inoculum potentials of the pathogen in infected seeds. However, the rates varied according to the cultivar and environment temperature in the early stage of plant development (Figure 6-A and B). For the Cultivar 'Helio 250' the highest average transmission rate (\% symptomatic plants) was observed when the seeds were infected by the isolate CMLAPS 423, with increments close to $6 \%$ to $31 \%$ and $12 \%$ to $37 \%$ at a temperature of $20^{\circ} \mathrm{C}$ (A) and $25^{\circ} \mathrm{C}(\mathrm{B})$, respectively, proportional to the increase of the inoculum potential. In seeds of this same cultivar infected by isolate CMLAPS 250, these rates varied in the range of nill to $31 \%$ and nill to $18 \%$ at temperatures of $20^{\circ} \mathrm{C}(\mathrm{A})$ and $25^{\circ} \mathrm{C}(\mathrm{B})$, respectively, depending on the inoculum potential. Similar results were observed for cultivar 'Helio 253', in which seeds were inoculated with isolate CMLAPS 423 and had the highest rates of transmission with symptomatic infection for both temperatures.
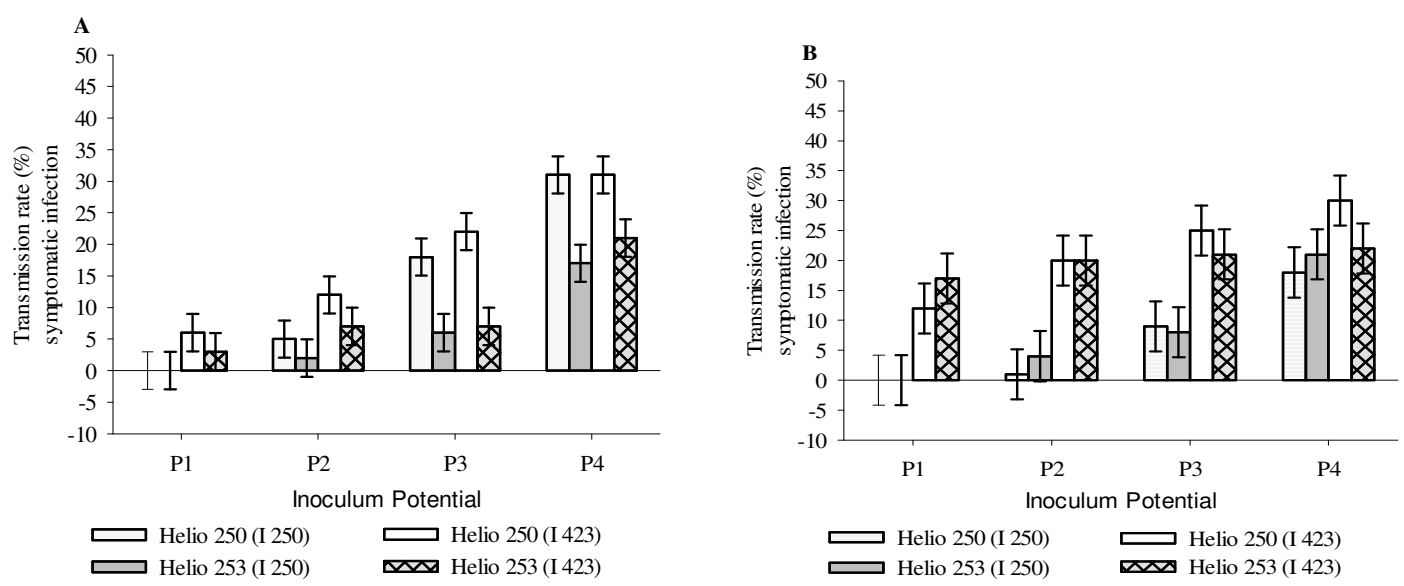

Figure 6. Values of transmission rate (\%) of isolates of S. sclerotiorum (CMLAPS 250 and CMLAPS 423) from sunflower seeds (cultivars Helio 250 and Helio 253) to plants with symptomatic infection cultivated in growth chamber with controlled temperature $\left(20^{\circ} \mathrm{C}-(\mathrm{A})\right.$ and $\left.25^{\circ} \mathrm{C}-(\mathrm{B})\right)$. Bars represent Tukey 0.05 mean separation test; overlapping bars indicate lack of significant difference.

The transmission of the pathogen to asymptomatic plants was not observed in this study as demonstrated by the normal isolation procedures and confirmed by incubation of plant fragments on semi-selective agar bromophenol (Neon), demonstrating the absence of the fungus in tissues of sunflower plants without disease symptoms.

Regarding the total transmission rate of $S$. sclerotiorum (Figure $7-\mathrm{A}$ and $\mathrm{B}$ ), the results varied according to temperature, fungal isolates and sunflower cultivars. In general, the highest rates were observed for the isolate CMLAPS 250, independent of cultivar and temperature, the mean values being $52.2 \%$ to $77.2 \%$. For the isolate CMLAPS 423, the mean values of transmission rates were $48.5 \%$ to $71.7 \%$ at both temperatures. The lower rates of total transmission of $S$. sclerotiorum were observed in the lowest inoculum potentials. 

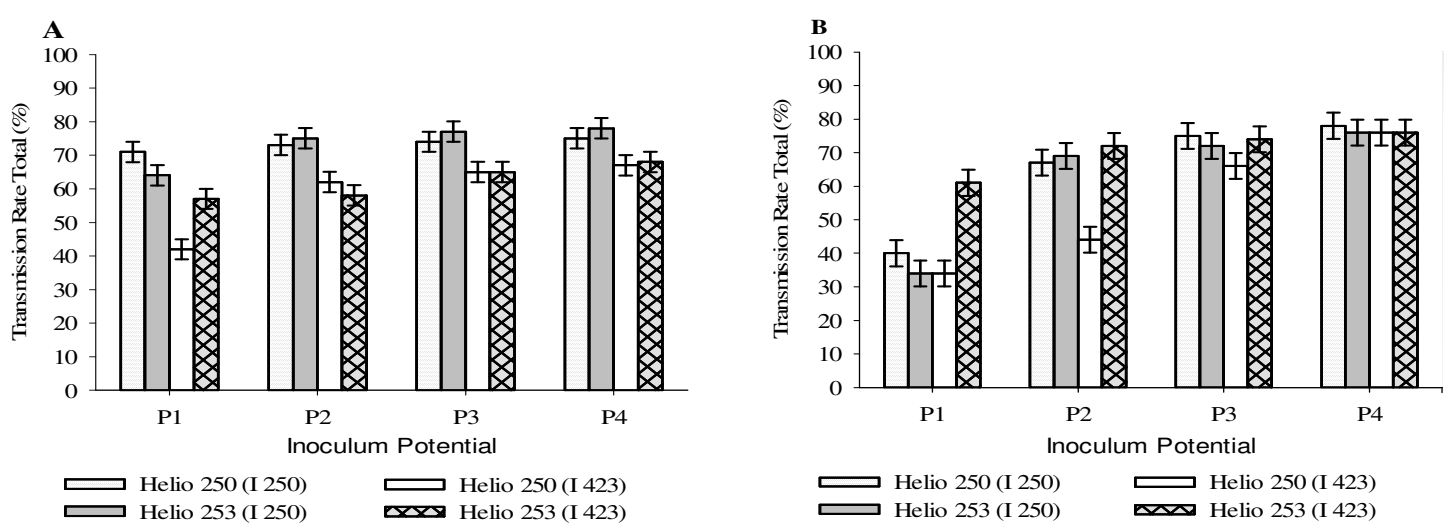

Figure 7. Values of total transmission rate (\%) of S. sclerotiorum (isolated CMLAPS 250 and CMLAPS 423) in sunflower seeds cultivars 'Helio 250' and 'Helio 253' in different condition of cultivation $\left(20^{\circ} \mathrm{C}\right.$ (A) and $25^{\circ} \mathrm{C}-(\mathrm{B})$ ). Bars represent Tukey 0.05 mean separation test; overlapping bars indicate lack of significant difference.

\section{DISCUSSION}

The association of S. sclerotiorum with sunflower seeds is known well from literature but the intensity of this interaction is little investigated and understood. From epidemiology view the ocurrence of that pathogen in seeds of that species may lead do various consequences, starting with low plant establishment in the field and then causing reduction in yields and being an efficient mean of disease dissemination. The internal presence of S. sclerotiorum in sunflower seeds was able to cause serious damages to the early development of this crop. In general, the higher inoculum potentials caused the higher seed germination reductions as well as plant development after emergence. Although $S$. sclerotiorum may be considered a soil-borne organism it was clear that its association to sunflower seeds is also an important factor affecting seed quality for planting.

An interesting factor observed in this study was the effects of the mycelium infection of sunflower seeds in causing drastic damages to seed quality and then representing a serious risk for growers using infected seeds. From the results of different evaluation tests, it was clear that internal inoculum of $S$. sclerotiorum is able to cause serious reduction in the germination rates and in plant vigour in the early stage development of the infected plants. At the lowest level of inoculum potential of $S$. sclerotiroum the mean values of germination of sunflower seeds were $86 \%$ and the emergence speed index of 1.1, under the most favorable temperature, $20^{\circ} \mathrm{C}$, for white mold development. The most severe effects of the pathogen on seed germination and plant vigour occurred at the highest inoculum potential, $\mathrm{P} 4$. The reduction of the mean value of seed germination was $44.3 \%$ in relation to the control (non inoculated seeds). In relation to vigour, the reduction in the mean value was of $52 \%$, reaching $94 \%$ at the highest inoculum potential of the pathogen. In literature, no quantification has been found as to the effect of $S$. sclerotiorum inoculum from sunflower seeds. That may be explained by the difficulty to find appropriate methodology to perform that evaluation. In that respect the use of the osmotic technique as described by Machado et al. (2012) that measurement is made possible.

In relation to the influence of mycelium inoculum of $S$. sclerotiorum on the plant establishment in this study it was clear the strong action of the pathogen on that variable, which was evaluated at two stages of plant development. In general the impact on that variable followed the same pattern as observed for seed germination and plant vigour. At the highest inoculum potentials the effect of S. sclerotiorum was more severe. There was a correlation between inoculum potentials and reductions of mean values of stands evaluated on twelve and fifty-five days after sowing.

With regard the reaction of both sunflower cultivars to both $S$. sclerotiorum isolates, no marked difference was detected between them, meaning that those factors may not play a similar role as temperatures and inoculum potentials on that interaction although further investigation should be conducted in this research line, in which a higher number of sunflower cultivars and Sclerotinia isolates should be used. 
Potential effects of other important pathogenic fungi in seeds of important crops in Brazil, such as Fusarium oxysporum f. sp. phaseoli in bean seeds, Colletotrichum gossypii var. cephalosporioides and Fusarium oxysporum f. sp. vasinfectum in cotton seeds, Stenocarpella maydis and $S$. macrospora in maize seeds have been reported in literature and in general inoculum potential in those cases is also responsible for the determination of variable levels of damage to seed performance and establishment of plant population in fields (COSTA et al., 2003; ARAÚJO et al., 2006; SOUSA et al., 2008).

The study on seed transmissibility of $S$. sclerotiorum in sunflower provides a clear understanding about the close interaction of this pathogen and seeds of the two sunflower cultivars used in this research. The transmission rates of the pathogen varied according to inoculum potential and temperature, the higher rates being observed at the highest inoculum potentials and under lower environment temperature. The higher proportion of dead seedlings in pre-emergence stage show the great potentiality of mycelium infection by $S$. sclerotiorum in causing drastic damages to seed performance. Because its ability to survive in soil for many years, as dormant sclerotia, dead seedlings from seed infection represent an important source of inoculum of white mold in practice. From the epidemiological view such transmission pattern means an alternative way to guarantee the disease in the field with serious implications for growers. Investigation conducted by $\mathrm{Tu}$ (1988) on white mold in beans had shown that $S$. sclerotiorum was able to survive in infected seeds as dormant mycelium in testa and cotyledons, and the rate of survival varied from $85 \%$ to $89 \%$ and did not change appreciably over a 3-year period.
Interesting to note also in this investigation that even at low level inoculum potential, $S$. sclerotiorum was able to be transmitted to seedling and emerged plants at high proportion. At potential $\mathrm{P} 1$, which consisted in exposing seeds to the fungal colony for 24 hours, the total transmission rate was $50.4 \%$; whereas at the highest potential (P4) transmission rate was $74.3 \%$. Although similar transmission rates were observed for the two sunflower cultivars and the two isolates of the pathogen used in this work, caution should be taken in making any general conclusion on the effect of those variables. A more representative number of cultivars of sunflower and of isolates of $S$. sclerotiorum should be considered for a better understanding of that interaction.

From the examination of $S$. sclerotiorum infection in emerged plants, as part of the determination of transmission rates of this pathogen, no infection was detected in asymptomatic plants. In terms of diagnosis and management of this disease, that fact is quite relevant as asymptomatic plants in other pathosystems may be infected by their pathogens and that may be the cause of serious consequences for growers (Oren et al., 2003; Vallad et al., 2005). In that direction, further investigation should be conducted for confirmation.

\section{ACKNOWLEDGEMENTS}

The authors express their thanks to Conselho Nacional de Desenvolvimento Científico e Tecnológico (CNPq) and Coordenação de Aperfeiçoamento de Pessoal de Nivel Superior (CAPES) for the support in the development of this work.

RESUMO: A área cultivada de girassol no Brasil tem se expandido consideravelmente, nos últimos anos, como resultado do elevado interesse na produção de biodiesel. Como consequência do crescimento da cultura, a ocorrência de várias doenças vem devastando as áreas plantadas com girassol. Este estudo avaliou os efeitos da associação de sementes de girassol infectadas por Sclerotinia sclerotiorum e as taxas de transmissão do patógeno a partir destas sementes infectadas, considerando os fatores que podem interferir nesta interação. Foram utilizados, neste trabalho quatro potenciais de inóculo, dois isolados de fungo, duas cultivares de girassol, 'Helio 250' e 'Helio 253', e duas temperaturas de crescimento, $20^{\circ} \mathrm{C}$ e $25^{\circ} \mathrm{C}$. Sanidade e germinação das sementes, índice de velocidade de emergência e população de plantas foram as variáveis analisadas. A partir dos resultados, o aumento do nível do potencial de inóculo levou a uma redução gradual nos valores de germinação, índice de velocidade de emergência e população de plantas, independente da cultivar, do isolado fúngico e da temperatura. As maiores taxas de transmissão foram observadas nos níveis de potencial de inóculo mais elevados, atingindo níveis próximos de 80\%. Estes resultados são indicativos sobre a importância do inóculo de S. sclerotiorum associado com sementes de girassol, tanto na disseminação do inóculo do patógeno, quanto como causa de possíveis danos em condições de campo.

PALAVRAS-CHAVE: Helianthus annuus. Condicionamento fisiológico. Transmissão. Mofo branco. 


\section{REFERENCES}

ARAÚJO, D. V.; POZZA, E. A.; MACHADO, J. C.; ZAMBENEDETTI, E. B.; CELANO, F. A. O.; CARVALHO, E. M.; CAMARGOS, V. N. Influência da temperatura e do tempo de inoculação das sementes de algodão na transmissibilidade de Colletotrichum gossypii var. cephalosporioides. Fitopatologia Brasileira, Brasilia, v. 31, p. 35-40, 2006.

BAKER, K. F.; SMITH, S. H. Dynamics of seed transmission of plant pathogens. Annu Rev Phytopathology, St. Paul, v. 4, p. 311-332, 1966.

BERGSTROM, G. C.; SHAH, D. A. Temperature dependent seed transmission of Stagonospora nodorum in wheat. European Journal Plant Pathology, Netherlands, v. 106, p. 837-842, 2000.

http://dx.doi.org/10.1023/A:1008723823196

BOLAND, G. J.; HALL, R. Index of plant hosts of Sclerotinia sclerotiorum. Canadian Journal Plant Pathology, Guelph, v. 16, p. 93-108, 1994.

BOLTON, M. D.; THOMMA, B. P.; NELSON, B. D. Sclerotinia sclerotiorum (Lib.) de Bary: biology and molecular traits of a cosmopolitan pathogen. Molecular Plant Pathology, Bristol, v. 7, p. 1-16, 2006. http://dx.doi.org/10.1111/j.1364-3703.2005.00316.x

BRASIL. Ministério da Agricultura, Pecuária e Abastecimento. Manual de análise sanitária de sementes. Ministério da Agricultura, Pecuária e Abastecimento. Secretaria de Defesa Agropecuária. Brasília, DF: MAPA/ACS, p. 200, 2009a.

BRASIL. Ministério da Agricultura, Pecuária e Abastecimento. Regras de análise de sementes. Ministério da Agricultura, Pecuária e Abastecimento. Secretaria de Defesa Agropecuária. Brasília, DF: MAPA/ACS Brasília, DF: p. 399, 2009b.

COSTA, M. L. N.; MACHADO, J. C.; GUIMARÃES, R. M.; POZZA, E. A.; ORIDE D. Inoculação de Fusarium oxysporum f.sp. phaseoli em sementes de feijoeiro através de restrição hídrica. Ciência e Agrotecnologia, Lavras, v. 27, p. 1023-1030, 2003.

MACHADO, J. C.; BARROCAS, E. N.; COSTA, M. L. N.; GUIMARÃES, R. M.; MACHADO, C. F. Uso da tecnica de restrição hídrica ou "condicionamento osmótico" em patologia de sementes. In: Wilmar C. da Luz (Org.) Revisão Anual de Patologia de Plantas. Passo Fundo, RS: RAPP, v. 20, p. 37-63, 2012.

MAGUIRE, J. D. Speed of germination-aid in selection and evaluation for seedling emergence and vigor. Crop Science, Madison, v. 2, p. 176-177, 1962. http://dx.doi.org/10.2135/cropsci1962.0011183X000200020033x

MICHEL, B. E.; RADCLIFFE, D. A. Computer program relating solute potencial to solution composition for five solutes. Agronomy Journal, Madison, v. 87, p. 131-136, 1995.

NAPOLEÃO, R.; NASSER, L.; LOPES, C.; CAFÉ FILHO, A. Neon-S, novo meio para detecção de Sclerotinia sclerotiorum em sementes. Summa Phytopathologica, Botucatu, v. 32, p. 180-182, 2006.

NASSER, L. C. B.; ARANCIBIA, R. C.; NAPOLEÃO, R. Uso do meio Neon modificado para determinação de Sclerotinia sclerotiorum em sementes de feijão produzidas em áreas irrigadas do cerrado. Fitopatologia Brasileira, Brasilia, v. 24, p. 309, 1999.

OREN, L.; EZRATI, S.; COHEN, D.; SHARON, A. Early events in the Fusarium verticillioides-maize interaction characterized by using a Green Fluorescent Protein-Expressing transgenic isolate. Applied Environmental Microbiology, Washington, v. 69, p. 1695-1701, 2003. http://dx.doi.org/10.1128/AEM.69.3.1695-1701.2003 
PERES, A. P.; NASSER, L. C. B.; MACHADO, J. C. Use of semi-seletive media for detection os Sclerotinia sclerotiorum on bean and soybean seeds. Fitopatologia Brasileira, Brasília, v. 27, p. 123-127, 2002. http://dx.doi.org/10.1590/S0100-41582002000200001

SOUSA, M. V.; MACHADO, J. C.; PFENNING, L. H.; KAWASAKI, V. H.; ARAÚJO, D. V.; SILVA, A. A.; MARTINI NETO, A. Métodos de inoculação e efeitos de Fusarium oxysporum f. sp. vasinfectum em sementes de algodoeiro. Tropical Plant Pathology, Brasilia, v. 33, p. 41-48, 2008.

TU, J. C. The role of White mold-infected white bean (Phaseolus vulgaris L.) seeds in the dissemination of Sclerotinia sclerotiorum (Lib.) de Bary. Journal of Phytopathology, Berlin, v. 121, p. 40-50, 1988. http://dx.doi.org/10.1111/j.1439-0434.1988.tb00951.x

VALLAD, G. E.; BHAT, R. G.; KOIKE, S. T.; RYDER, E. J.; SUBBARAO, K. V. Weedborne reservoirs and seed transmission of Verticillium dahliae in lettuce. Plant Disease, St. Paul, v. 89, p. 317-324, 2005. 